\title{
PENGARUH PENDIDIKAN KESEHATAN TERHADAP SIKAP MASYARAKAT KEPADA SUSPECT COVID-19 DI DUSUN AUR KUNING
}

Achmad Vindo Galaresa ${ }^{1}$, Heri Syahriansyah ${ }^{2}$

STIKes Pekanbaru Medical Center

Pekanbaru, (0761)848100

Email: vindo92@gmail.com

\begin{abstract}
ABSTRAK
Latar Belakang: Virus Corona atau severe acute respiratory syndrome coronavirus 2 (SARS-CoV-2) adalah virus yang menyerang sistem pernapasan, penyakit karena infeksi virus ini disebut Covid-19. Kasus positif Covid-19 bertambah sebanyak 399 kasus sehingga total tercatat 4.241 sampai 12 April 2020 dan penelitian dilaksanakan selama kurang lebih 1 bulan. Masyarakat di Dusun Aur Kuning menjauhi pendatang baru, Suspect Covid-19 dan pasien yang sudah sembuh dari virus Covid-19 sehingga perlu diberikan edukasi dan pendididikan Kesehatan untuk merubah sikap masyarakat tersebut. Tujuan : mengetahui pengaruh pendidikan kesehatan terhadap sikap masyarakat kepada Suspect Covid19 di Dusun Aur Kuning. Metode: Pre experimental dengan pendekatan one group pretest-posttest. Besar sampel 150 orang responden di Dusun Aur Kuning Desa Pebenaan Kecamatan Keritang Kabupaten Indragiri Hilir Riau, menggunakan total sampling. Hasil: Hasil uji Wilcoxon diperoleh $\mathrm{p}$ value $<0.025$ lebih kecil daripada nilai alpha $(\mathrm{p}<0,05)$ Kesimpulan: pendidikan kesehatan tentang covid - 19 memberikan pengaruh terhadap sikap masyarakat di dusun aur kuning.
\end{abstract}

Kata Kunci: Pendidikan Kesehatan, Sikap Masyarakat, Suspect Covid-19

\section{ABSTRACT}

Background: Coronavirus or severe acute respiratory syndrome coronavirus 2 (SARS-CoV-2) is a virus that attacks the respiratory system, the disease caused by this viral infection is called Covid-19. Positive cases of Covid-19 increased by 399 cases so that the total was recorded at 4,241 until April 12, 2020, and the research was carried out for approximately 3 months. People in Aur Kuning Hamlet stay away from newcomers, suspect Covid-19 and even patients who have recovered from the Covid-19 virus so that it is necessary to provide education and health education to change the attitude of the community. Objective: To determine the effect of health education on people's attitudes to Covid-19 suspects in Aur Kuning Hamlet. Method: Pre experimental with one group pretest-posttest approach. The sample size is 150 respondents in Aur Kuning Hamlet, Pebenaan Village, Keritang District, Indragiri Hilir Regency, Riau, using total sampling. Results: Wilcoxon test results obtained p-value $<0.025$ which is smaller than the alpha value $(\mathrm{p}<0.05)$. Conclusion: health education about Covid-19 influences people's attitudes in the hamlet of Aur kuning.

Keywords: Health Education, Community Attitude, Suspect Covid-19 


\section{Latar Belakang}

Kasus virus corona muncul dan menyerang manusia pertama kali di provinsi Wuhan, China. China melaporkan secara resmi adanya virus corona kepada Organisasi Kesehatan Dunia (WHO) pada 31 Desember 2019. Awal kemunculannya diduga merupakan penyakit pneumonia, dengan gejala serupa sakit flu pada umumnya. Gejala tersebut di antaranya batuk, demam, letih, sesak napas, dan tidak nafsu makan. Namun berbeda dengan influenza, virus corona dapat berkembang dengan cepat hingga mengakibatkan infeksi lebih parah dan gagal organ (WHO, 2020).

Kondisi darurat ini terutama terjadi pada pasien dengan masalah kesehatan sebelumnya. Karena penularan virus corona yang sangat cepat inilah Organisasi Kesehatan Dunia (WHO) menetapkan virus corona sebagai pandemi pada 11 Maret 2020. Status pandemi atau epidemi global menandakan bahwa penyebaran Covid-19 berlangsung sangat cepat hingga hampir tak ada negara di dunia yang dapat memastikan diri terhindar dari virus corona (Mona, 2020).

Wabah ini mulai masuk ke Indonesia pada sekitar awal Maret 2020 dengan dikabarkannya dua warga negara Indonesia yang positif terjangkit Covid-19. Semakin hari terus bertambah orang-orang yang terjangkit Covid19 bahkan sampai 12 April 2020 di Indonesia, kasus positif Covid-19 bertambah sebanyak 399 kasus sehingga total tercatat 4.241 kasus (Widiyani, 2020).
Media konvensional dan media online memberikan dampak yang sangat signifikan pada perspektif masyarakat terhadap sikap atau perlakuan masyarakat kepada penderita positif dan suspect selama perkembangan Covid-19 di Indonesia. Perlakuan yang tergambar dalam pikiran mereka muncul dalam sikap dan perilaku mereka, hal ini bisa dikategorikan dalam empat jenis psikologi trauma yang ditimbulkan akibat pandemic Covid-19. Trauma pertama adalah trauma individu yang tercerminkan dengan penarikan sosial. Jenis trauma kedua adalah hysteria. Hal yang terjadi pada beberapa kasus mereka berteriak, melukai diri sendiri dan melukai petugas kesehatan,. Jenis trauma ketiga adalah kekerasan terhadap diri sendiri dan jenis trauma keempat adalah kekerasan secara kolektif. Jenis ke empat ini terjadi di komunitas yang menyebabkan masyarakat panik, takut dengan adanya pendatang baru sehingga menjauhinya serta bila ada yang terkonfirmasi positif atau suspect Covid-19. Hal-hal tersebut menyebabkan masyarakat tidak memberikan perawatan yang diperlukan terhadap pasien atau suspect Covid19 yang ada di daerahnya (Abdullah, 2020).

Menurut Abdillah (2020) Berita terkait Covid-19 telah merajai trending sepanjang hari terutama semenjak status pandemi global disandang Covid-19. Dari media online dan elektronik beredar informasi terkait penolakan warga terhadap pemakaman jenazah penderita Covid-19. Bahkan tidak hanya pasien/penderita dan keluarga saja yang mendapatkan stigma, namun tenaga perawat yang merawat pasien 
Covid-19 juga mendapatkan stigma dari masyarakat. Bahkan ada sejumlah perawat yang sampai diintimidasi, diusir dari kontrakan karena khawatir akan membawa virus penyebab Covid-19.

Studi pendahuluan yang dilakukan peneliti memperoleh data 38 suspect pada bulan Maret-Mei yang ada di Desa Pebenaan, seratus responden di Dusun Aur Kuning bersikap tidak baik dan menjauhi pendatang baru. Selanjutnya, 50 responden menganggap dan bersikap biasa saja terhadap pendatang baru di desa Pebenaan. Hal tersebut disebabkan kurang nya pendidikan kesehatan tentang Covid-19 di masyarakat sehingga pendatang baru dianggap oleh masyarakat sebagai manusia pembawa virus yang berbahaya dan perlu dijauhi serta jadi bahan gunjingan.

Berdasarkan uraian diatas peneliti memandang perlu untuk melakukan penelitian mengenai pengaruh pendidikan kesehatan terhadap sikap masyarakat kepada suspect Covid-19 di Dusun Aur Kuning.

\section{Metode}

Penelitian dilakukan Dusun Aur Kuning, Desa Pebenaan, Kecamatan Keritang, Kabupaten Indragiri Hilir, Riau dengan jumlah sampel 150 responden. Jenis penelitian ini adalah adalah pre experimental dengan desain one group pretest-posttest. Teknik pengambilan sampel dalam penelitian ini menggunakan total sampling, sehingga seluruh 150 orang dalam populasi menjadi sampel dalam penelitian ini. Data yang diperoleh dalam penelitian ini merupakan data primer. Sebelum mendapatkan intervensi, responden mengerjakan pretest yang menilai sikap terhadap suspect Covid-19. Kuesioner ini dibuat oleh peneliti, memiliki 30 pertanyaan dengan skala likert. Kuesioner sudah diuji validitas dan reliabilitasnya. Dengan kategori skor $X<100$ memiliki sikap negative dan skor $X \geq 100$ memiliki sikap positif.

Setelah mengerjakan pre-test sikap, responden mendapatkan intervensi berupa pendidikan kesehatan (penkes) sekali seminggu selama 3 minggu berturut-turut. Peneliti dan tim kesehatan puskesmas Dusun Aur Kuning berjumlah 15 orang melakukan penkes tersebut. Sebelumnya telah dilakukan persamaan persepsi selama dua minggu sebelum pelaksanaan penelitian dan briefing setiap akan melakukan pendidikan kesehatan. Metode yang digunakan selama pendidikan kesehatan adalah diskusi dan ceramah selama 30 menit dengan media pendidikan kesehatan berupa leaflet. Setelah ceramah, kegiatan dilanjutkan diskusi dan tanya jawab.

Isi materi pendidikan kesehatan antara lain, minggu pertama definisi dan tanda gejala Covid-19, minggu kedua cara penularan dan pencegahan Covid-19, minggu ketiga cara mengurangi stres akibat Covid-19 dan pada minggu ke empat diberikan kuesioner penilaian sikap post-test yang isi kuesionernya sama dengan kuesioner saat pre-test. 


\section{Hasil}

Dari hasil penelitian dapat dijelaskan data demografi respoden berdasarkan pendidikan respoden, jenis kelamin dan usia ditampilkan pada tabel 1 .

Tabel. 1 Data Demografi

\begin{tabular}{|c|c|c|c|c|}
\hline No & Variabel & Kategori & $\begin{array}{c}\text { Freku } \\
\text { ensi }\end{array}$ & $\begin{array}{l}\text { Persentase } \\
\quad(\%)\end{array}$ \\
\hline \multirow{5}{*}{1} & \multirow{5}{*}{$\begin{array}{l}\text { Pendidik } \\
\text { an }\end{array}$} & $\begin{array}{c}\text { Tidak } \\
\text { Bersekolah }\end{array}$ & 6 & 4 \\
\hline & & SD & 51 & 34 \\
\hline & & SMP & 72 & 48 \\
\hline & & SMA & 21 & 14 \\
\hline & & Total & 150 & 100 \\
\hline \multirow{3}{*}{2} & \multirow{3}{*}{$\begin{array}{c}\text { Jenis } \\
\text { Kelamin }\end{array}$} & Laki-laki & 78 & 52 \\
\hline & & perempuan & 72 & 48 \\
\hline & & Total & 150 & 100 \\
\hline \multirow{4}{*}{3} & \multirow{4}{*}{ Usia } & Remaja & 20 & 13,3 \\
\hline & & Dewasa & 99 & 66 \\
\hline & & Lansia & 31 & 10,7 \\
\hline & & Total & 150 & 100 \\
\hline
\end{tabular}

Sumber: Data Primer

Berdasarkan data demografi sebagian

besar memiliki Pendidikan terakhir SMP sebanyak 72 orang responden (48\%), jenis kelamin paling banyak laki-laki sebanyak 78 orang responden (52\%), dan usia terbanyak dewasa sebanyak 99 orang responden (66\%).

Pengaruh Pendidikan Kesehatan Terhadap Sikap Masyarakat Kepada Suspect Covid-19 di Dusun Aur Kuning ditunjukan pada table 2 .

Tabel. 2

Pengaruh Pendidikan Kesehatan Terhadap Sikap Masyarakat Kepada Suspect Covid-19 di Dusun Aur Kuning

Variabel $\begin{gathered}\text { Pre } \\ \text { (Mean) }\end{gathered} \quad \begin{gathered}\text { Post } \\ \text { (Mean) }\end{gathered} \quad$ Pvalue

\begin{tabular}{cccc}
\hline Sikap & 72,04 & 74,75 & 0,025 \\
\hline
\end{tabular}

Berdasarkan hasil uji statistic wilcoxon mengenai pengaruh pendidikan kesehatan terhadap sikap masyarakat menunjukkan bahwa terdapat hubungan yang bermakna ( $\mathrm{p}$ value $=$ 0,025).

\section{Pembahasan}

Hasil penelitian yang diperoleh menujukkan hasil serupa seperti yang dilakukan oleh Yanti (2020) mengenai pengetahuan yang cukup dan benar mampu menggiring masyarakat bersikap semestinya dalam menghadapi dan mencegah penularan Covid-19.

Penelitian lain yang dilakukan oleh Sari mendapatkan hasil bahwa pengetahuan yang baik akan memberikan dampak pada sikap yang baik juga terhadap masalah Covid-19 dengan nilai p value $=0,04$ (Sari et al., 2021).

Hasil penelitian oleh Zhong menyatakan bahwa masyarakat akan berperilaku berbeda berdasarkan tingkat pendidikan mereka. tetapi yang jelas pengetahuan yang baik didukung dengan rasa optimisme terhadap penyelesaian pandemic Covid-19 ini akan membuat perilaku masyarakat menjadi lebih teratur dan taat sehingga tidak perlu menimbulkan kecemasan, penolakan dan stigma kepada penderita maupun suspect sehingga akan memunculkan tindakan positif pada lingkungan masyarakat (Zhong et al., 2020).

Berdasarkan hasil penelitan yang dilakukan peneliti dan beberapa jurnal pendukung hasil penelitian, ternyata semakin tinggi pendidikan seseorang maka akan semakin mempengaruhi sikap individu tersebut. Hal ini 
dikarenakan pendidikan kesehatan yang dilakukan peneliti merupakan informasi baru. Selama sebulan responden juga mendapat pengalaman terkait informasi yang diberikan dan membuat keputusan ketika menemui masalah terkait Covid-19.

\section{Kesimpulan}

Berdasarkan hasil penelitian yang telah dilakukan kepada 150 orang responden didapatkan hasil yaitu terdapat pengaruh pendidikan kesehatan terhadap sikap masyarakat kepada suspect Covid-19 di Dusun Aur Kuning. Dimana semakin bagus pendidikan kesehatan kepada mereka maka akan semakin baik perilakunya.

Peneliti menyarankan kepada peneliti selanjutnya yaitu: dapat memperpanjang waktu pemberian edukasi dengan menyesuaikan tingkat pendidikan di masyarakat agar maksimal. Selama pelaksanaan penelitian terdapat keterbatasan media pendidikan yang hanya berupa leaflet dikarenakan terkendala akses, peralatan dan medan menuju lokasi pendidikan kesehatan. Alangkah lebih baiknya peneliti berikutnya mampu mengembangkan media pendidikan yang mudah digunakan dan dibawa.

\section{Ucapan Terima Kasih}

Penulis mengucapkan terima kasih kepada seluruh pihak terkait yang telah mendukung dan memfasilitasi jalannya penelitian hingga publikasi. ternyata berkaitan dan benar. Hal tersebut menyebabkan seseorang yang mendapatkan informasi dan pengetahuan dapat bereaksi

\section{Daftar Pustaka}

Abdillah, L.A., 2020. Stigma Terhadap Orang Positif COVID-19.

Abdullah, I., 2020. COVID-19: Threat and fear in Indonesia. Psychol. Trauma Theory Res. Pract. Policy 12, 488-490. https://doi.org/10.1037/tra0000878.

Mona, N., 2020. Konsep isolasi dalam jaringan sosial untuk meminimalisasi efek contagious (kasus penyebaran virus corona di Indonesia). J. Sos. Hum. Terap. 2.

Sari, D.K., Amelia, R., Dharmajaya, R., Sari, L.M., Fitri, N.K., 2021. Positive Correlation Between General Public Knowledge and Attitudes Regarding COVID-19 Outbreak 1 Month After First Cases Reported in Indonesia. J. Community Health 46, 182-189. https://doi.org/10.1007/s10900-02000866-0

Widiyani, R. (2020). Latar Belakang Virus Corona, Perkembangan hingga Isu Terkini. Retrieved from detikNews: https://news.detik.com/berita/d4943950/latar-belakang-virus-coronaperkembangan-hingga-isu-terkini.

World Health Organization. (2020). Emergency: Coronavirus disease (COVID-19) pandemic.

Yanti, B., Wahyudi, E., Wahiduddin, W., Novika, R.G.H., Arina, Y.M.D., Martani, N.S., Nawan, N., 2020. Community Knowledge, Attitudes, And Behavior Towards Social Distancing Policy As Prevention Transmission Of Covid-19 In INDONESIA. J. Adm. Kesehat. Indones. 8 , 
https://doi.org/10.20473/jaki.v8i2.2020. 14

Zhong, B.-L., Luo, W., Li, H.-M., Zhang, Q.-Q., Liu, X.-G., Li, W.-T., Li, Y., 2020. Knowledge, attitudes, and practices towards COVID-19 among Chinese residents during the rapid rise period of the COVID-19 outbreak: a quick online cross-sectional survey. Int. J. Biol. Sci. 16,1745-1752.

https://doi.org/10.7150/ijbs.45221. 